\title{
Comprehension and Interpretation of English and Albanian Fixed Expressions
}

\author{
Suela Koça (Pici) \\ Lecturer at "F. S. Noli" University, Korçë \\ spicikoca@gmail.com \\ Alda Cicko (Jashari) \\ Lecturer at "F. S. Noli" University, Korçë \\ aldajashari@ymail.com
}

\section{Doi:10.5901/ajis.2013.v2n8p319}

\begin{abstract}
Processing and understanding this unique group of fixed expressions has been a topic of great importance for many scholars and language educators. The comprehension of an expression is a prerequisite for its acquisition. It deals with, among other things, how people learn to use them in their own language production. Using them in the proper context or situation is difficult in the native language (L1) and second language (L2) as well. There have been numerous studies on L1 and L2 comprehension and acquisition of these expressions but researchers have not come to an agreement about them. Different approaches suggest an L2 learner uses a variety of strategies (including guessing, using pragmatic knowledge, and experimentation) to decipher the meaning of an unknown expression. The problem addressed in this study is from the perspective of foreign language learners. Its purpose it to: 1) identify comprehension strategies used by intermediate level English language learners to understand the selected expressions in English and Albanian; 2) determine whether comprehension depends on the category of an expression (identical, similar, dissimilar to an expression in Albanian); and 3) discover their ability to use these expressions in different contexts. The results will be drawn from a questionnaire completed by EFL students.
\end{abstract}

\section{Introduction}

"Fixed expressions" pose problems in understanding and interpreting. They are considered as complex units since they consist of more than one word. Many authors agree that these complex units are syntactic expressions that exhibit lexical co-occurrence restrictions that cannot be explained in terms of regular rule-governed syntactic or semantic restrictions. The fact that kick the bucket means "die" does not follow from any underlying principle or from our knowledge of the world. The fact that we have to say spill the beans and not spill the peas does not follow from any grammatical rule but simply has to be learned even if we assume that this idiom is semantically compositional or analyzable. This means that in a sense, one could say that idioms are idioms by convention. Like all conventions, idioms have to be explicitly learned and remembered (Everaert et al. 1995, p.3).

In this paper we will first review some problems concerning the terminology and some of the major aspects of idiomatic expressions. Then we will describe the study that we have conducted with EFL students of our university in Korça by exploring the perspective of second language learners on idiomatic expressions. In the end, we will try to draw some conclusions based on the results of the questionnaire. Addressing the issue from the learners' perspective is necessary because learners' criteria for identifying idioms may sometimes differ from those of researchers due to the learners' unique interest in idioms: to learn to understand and use them (Liu 2008, p.4).

We shall now look at the reasons for the difficulties which foreign learners experience when trying to use idioms. Seidl $(1978, p .7)$ describes three major difficulties. She mentions that one of the main difficulties is that the learner does not know in which situations it is correct to use an idiom. Choice of words depends on the person one is speaking to and on the situation or place at the time. Another major difficulty is that the learner does not know if an idiom is natural or appropriate in a certain situation. This can only be learnt by careful listening to native speakers or careful reading of English texts which contain idioms. The third major difficulty is that of fixed idioms. It is important that the learner should be exact in his use of fixed idioms, as an inaccurate idiom may mean very little or even nothing at all to a native speaker. She also emphasizes that it is usually extremely unwise to translate idioms into English form one's own native language. One may be lucky that the two languages have the same form and vocabulary, but in most cases, the result will be utterly 
bewildering to the native speaker - and possibly highly amusing (p.8). Mastery of idiom comes only slowly, through careful study and observation, through practice and experience.

\section{Literature review}

This sections looks at the various terms used to describe these complex units, definitions, as well as some general aspects about them and setting limits on the expressions as part of our study.

\subsection{Terminology}

Terminology in this field has always been problematic... There is no generally agreed common vocabulary. Different terms are sometimes used to describe identical or very similar kinds of unit; at the same time, a single term may be used to denote very different phenomena (Moon 1998, p.2). So it is essential to clarify the kinds of unit which we will be discussing in this paper.

Fixed expression is a very general but convenient term, adopted from Alexander (1978, 1979), Carter (1987), and others, and used to cover several kinds of phrasal lexeme, phraseological unit or multi-word lexical item... (Moon 1998, p.2) According to her, fixed expression, like idiom, is unsatisfactory as a term... many fixed expressions of these types are not actually fixed. After discussing the difficulty of finding precise terms for these different expressions (fixed expressions and idioms) she writes: "I will retain it [fixed expression] for simplicity's sake. I will refer to fixed expressions (including idioms) as FEls (p.2). In other words,... she basically avoids the problem of separating idioms from the other fixed expressions. Of course, this does not mean that Moon does not distinguish the two categories in theory. She does, and somewhat vehemently, although she does not quite maintain the distinction in practice (Liu 2008, p.11). Other notions that cover most of these kinds of expressions are complex unit, fixed phrase, phraseme, phraseolexeme, and conventional expression. ${ }^{1}$

Even in Albanian there are several terms used to cover the same kinds of expressions. Çeliku (1962) in his study "Togfjalësha të qëndrueshëm foljorë në shqipen e sotme"2 states that verb fixed expressions are treated as grammatical and lexical units (p.194). Samara (1981) also states that "fixed expressions are those linguistic units which 'are totally lexicalized' or have 'a tendency for lexicalization'; they are semantically equivalent to a single word. They are not created at the moment of speaking, but are historically constructed. They have become fixed and are used as ready-made units just like words. Most of them are phraseological." Other terms used are phraseological units, fixed expressions (which are very common), locutions, phrases, etc. Recently, even the term idiomë (idiom) is used very often. For this reason, it is very important to decide the term that we are going to use in this paper. The set of expressions in our study covers fixed expressions with figurative meaning. We have deliberately selected only idiomatic expressions and avoided other kinds of fixed expressions as proverbs, routine formulae, sayings, similes, phrasal verbs etc. in order for our students not to get confused. We are going to refer to them as fixed expressions because they include not only idioms (in English), but even some very popular Albanian expressions, which are used in our region and which are very common in everyday speaking. We find 'fixed expression' as a very convenient term to describe the units we have included in our study.

\subsection{Different aspects of fixed expressions in English and Albanian}

In this section we will look at some aspects of fixed expressions which are idiomatic. Despite of the different approaches related to terminology or definition, there are some characteristics of these expressions which are common in both languages. It is important to stress that these expressions are not only colloquial, as many people believe. They can appear in different styles, either formal or informal (Seidl 1978, p.4). The idiomatic expressions consist of a number of words which, taken together, mean something different from the individual words of the expression when they stand alone. The way in which the words are put together is often odd, illogical or even grammatically incorrect. But there are other expressions which are completely regular and logical in their grammar and vocabulary. Because of these special features, we have to learn these expressions as wholes and often we cannot change any part of it (except perhaps, only the tense of the verb); e.g. in the expression to catch someone red-handed we cannot change any word from it to replace

\footnotetext{
${ }^{1}$ For a thorough overview of terminology see Barkema (1993)

2 "Verb fixed expressions in Albanian"
} 
with another one *to catch someone blue-handed or *to catch someone red-legged because the idiomatic meaning of the expression would be destroyed, but we can change the form of the verb according to its grammatical features (tense, aspect, person etc.); They caught him red-handed., or He was caught red-handed. This is true even in Albanian; e.g. ta kapësh dikë me presh në dorë (to catch someone with leek in his hands) is the Albanian equivalent of the above expression. We cannot change the word presh with domate (tomatoes) or dorë with këmbë (legs), but we can change the form of the verb: $E$ kapën me presh në dorë. I kapën me presh në dorë., or $E$ kishin kapur me presh në dorë., etc. Both languages, English and Albanian, are very rich in idiomatic expressions. In fact, it is difficult to speak any of these languages without using them. Native speakers are very often not aware that they are using these expressions. On the other hand, non-native learners find it difficult to learn and use them in the proper way. Only careful study and exact learning will help (Ibidim).

There are many sources of these expressions in both languages. The most important thing about them is their meaning. For this reason, native speakers do not pay attention to their structure even when they are grammatically incorrect, by and large is one example, in which we have the combination of a preposition with an adjective. But if the source of the expression is known then it is easier to guess its meaning. Many expressions come from every-day life, from home life, e.g. a storm in a tea-cup (shumë zhurmë për asgjë), to be born under a lucky star (të lindësh me këmishë), a blind date (takim me një të panjohur) or in Albanian, paraja e bardhë për ditë të zezë (to save for a rainy day), kokë e këmbë (head over hills). There are many which have to do with food and cooking, e.g. a fish out of water (si peshku pa ujë), the salt of the world (kripa e botës) or in Albanian, e ka xhepin kukurec (to have pockets full), gjella me kripë e kripa me karar (enough is enough), etc. Many other expressions include parts of the body as; to twist someone round one's (little) finger (ta vërtitësh dikë me gishtin e vogël), to lead someone by the nose (ta tërheqësh dikë prej hunde), or to have something on the tip of one's tongue (ta kesh diçka në majë të gjuhës), which are used in the same way in English and Albanian. There are many other sources as nautical life and military life, animals, colours and so on and so forth.

These expressions take many different forms or structures, which means that they can be very short or rather long, e.g. there are combinations of adjective and noun; a blind date, a wet blanket, a cold war (lufta e ftohtë), or in Albanian, artet e bukura (the fine arts), bukë e vjetër (old friends), delja e zezë (the black sheep), etc. But some other expressions are much longer, e.g. to keep one's fingers crossed (të kryqëzosh gishtat), to raise one's glass to someone (të ngresh dolli për shëndetin e dikujt), to put a spoke in someone's wheel (t'i vësh shkopinjtë në rrotë dikujt), etc., which are used in the same way in both languages.

\section{Description of the study}

There have been numerous studies on L1 and L2 comprehension and acquisition of fixed expressions but researchers have not come to an agreement about them. Different approaches suggest an L2 learner uses a variety of strategies (including guessing, using pragmatic knowledge, and experimentation) to detect the meaning of an unknown expression. The results of our study are drawn from a questionnaire completed by EFL students.

The participants were all EFL Albanian students of Korça University. They are of an upper-intermediate level. They were given a written questionnaire containing two lists of expressions one in Albanian (40) ${ }^{3}$ and the other in English (40) ${ }^{4}$. The subjects' task was three fold: First they were requested to give the definition of each expression or at least try to explain their meanings. For those that they were uncertain of or did not know the meaning, they were requested to make a guess and write down a paraphrase. Secondly, once finished with this first task they were given two other lists in which half of the expressions were used in sentences to see if the students could guess the meanings of the unknown expressions in the first place. While for the second half of the expressions was given the correct definition for the students to check themselves and see if they were right and find out the meanings of the unknown expressions. Thirdly, they were also requested to produce simple sentences of their own to find out if they had understood the unknown expressions in the right way. There were also some simple questions that the students had to answer:

Which of these expressions (either in English or Albanian) have you heard?

How much does the definition help you to understand the meaning of the unknown expressions in L1 and L2?

\footnotetext{
${ }^{3}$ The expressions are taken from "Shprehje popullore nga rrethi i Korçës", collected by N. Mustafa, SF. 1, (1984).

${ }^{4}$ The sources from where they were taken are: "Illustrated American Idioms" by Curry, (1994) and "English idioms and how to use them", by Seidl/McCordie, (1978).
} 
How much does the context help you?

Do you find it difficult to use these expressions in sentences of your own?

Which of the English expressions have equivalents in Albanian?

The aim of this modest study was to investigate how definition and context helped them in order to assign a meaning to the unknown expressions in both L1 and L2. Sometimes students made mistakes; they were sure that they knew the meaning of the expression, and that was not always the case. Sometimes they confused two similar expressions and the like. The main problems that we noticed were as follows:

\subsection{Giving the definition}

What we noticed from the students' answers was that they found it hard to give the proper definition to describe the meaning of the expression, even when they knew it. Sometimes they prefer to make sentences to describe them. It should be emphasized that they knew almost all the expressions in Albanian (probably because they were expressions used in our region in everyday speaking). On the other hand, not only were they right in explaining their meanings but also used other fixed idiomatic expressions, similar to the ones given, to describe them: e.g.

Godet me një çekan dikush (në një vrimë i bie fyellit dikush) - someone always does or says the same thing

Sa ke kopsën, hap vrimën (shtriji këmbët sa ke jorganin) - do as much as you can, not more

I ngeli këmba në gurë (i ngeci sharra në gozhdë) - something prevents someone from doing something

But, there is an Albanian expression I ngriftë dhjamët e syrit, which none of the students understood, although it is used in a sentence: I ngriftë dhjamët e syrit, qenit se na plasi! They do understand that it refers to a kind of curse, but they are not right in detecting its exact meaning, which is wishing death to someone who has upset you a lot, just die! As far as English expressions are concerned, we can say that it was hard for the students to give the right definition to describe them unless they were known to them. They could describe the meanings of the known expressions and the ones which were similar to Albanian (see section 3.3), in the first place.

When it was given the correct definition, the students found it easier to interpret the meaning of the unknown expressions, especially in English, which means that, in most of the cases, after reading the definition they could make correct sentences of their own to use them. Here are some examples of their sentences after reading the definitions. We cannot include all of them, but we have presented only some of the most typical cases: 5

A wet blanket: She always is like a wet blanket. Don't invite him, he is going to be a wet blanket in the party. ${ }^{*}$ This boring meeting needs a wet blanket.

Most of the students did not give any sentences at all, probably because they did not understand it.

To be born under a lucky star: He always wins, he was born under a lucky star. She is a rich woman, she was born under a lucky star. Not all the people are born under a lucky star like you. këmishë.

Not only did most of the students use it correctly, but they also provided the Albanian equivalent of it: të lindësh me

To get the sack: I'm happy he got the sack, he was so lazy. She got the sack when she protested about her payment. *They got me the sack. *'m surprised, it got me the sack. *He got a sack and missed his job.

Only half of the students made sentences, but some of them did not use the expression correctly.

To give someone the cold shoulder: I don't think it's a good idea to give your sister the cold shoulder. She didn't like him, so she gave him the cold shoulder. You always give me the cold shoulder. *After what she did, she deserves to give a cold shoulder.

It was not difficult for the majority of the students to use it correctly.

To kick the bucket: The oldest man in your village kicked the bucket yesterday. After having suffered for so long, he kicked the bucket. My neighbor kicked the bucket last week.

Although this expression is one of the most difficult to guess, when it is explained, the students use it correctly. All of them were right.

To catch someone red-handed: finally the police caught him red-handed. He was caught red-handed when he was trying to rob the bank.

\footnotetext{
5 The asterisk (*) is used to mark the incorrect uses.
} 
Almost all the students used this expression correctly. They also paraphrased it by providing its Albanian equivalent: ta kapësh dikë me presh në dorë.

There are some very common expressions in English such as: take it easy, get the message, or by and large, which almost all the students know.

\subsection{Usage in context}

Some expressions are too difficult to guess correctly because they have no association with the original meaning of the individual words, especially in L2. Even when they are used in context, it is not easy to detect their meanings exactly. Here are some examples from the questionnaire to see how the students tried to describe the expressions after reading the sentences in which they were used. It is obvious that we have only given some of them:

Get it in the neck (to be blamed or punished): to be punished for something that you have done; to be criticized; to pay the consequences of an action that someone did; when someone makes a mistake and it brings consequences; *to be taken aback.

We have to say that some of the students did not detect its meaning at all.

Hard act to follow (excellent performance; one difficult to surpass in quality): when somebody is excellent in doing something, we find it hard to imitate; a person who is difficult to be imitated; *a difficult case; *something that you cannot do, it is difficult; *someone who is hard to be followed.

This expression is not understood in the proper way, only 2 students were correct. Most of the others considered it as used for a thing, not a person, although the sentence given to them referred to a person: Rosalie is a hard act to follow. She is an excellent speaker.

Head over hills (upside down/ completely): *to be in love with somebody; *to be injured; *when someone is not concentrated.

Only one of the students was correct. Most of them related its meaning with being in love, although the example given to them was not connected to it: Mary stumbled and fell head over hills down the stairs.

Out of circulation (not out in the company of other people): not to appear for some time; a person missing for a long time; something or someone not seen for a long time; *when something is out of use; *not knowing what happened for some time; *not in good condition.

Most of the students have described it as referring to a thing not used any more, although the example given to them was: Mary was ill and out of circulation for about a month.

Pop the question (ask someone to marry): to ask somebody to marry you; to propose marriage; *to analyze the question; *answer a question; raise a question; *trying for something new.

As it can be seen, most of the students relate its meaning with ways of questioning and only two of them were correct. This happens because this expression is very much culture-related and Albanian students cannot detect its meaning even in context: I'm really uptight because I plan to pop the question tonight.

Straight from the horse's mouth (directly from the person or place where something began, a reliable source): to hear something from a trustful person, to hear something directly; to get information directly from a person who is involved; *from the person in question.

We can say that this expression was difficult; only 2 students were correct and detected its meaning from the example given: He got the news straight from the horse's mouth - his mother.

As it can be noticed from the examples, although all of these expressions were used in context, the students were not able to detect their exact meanings at all, or even when they tried to guess them, detected the wrong ones. We suppose that one of the main reasons is that these expressions are not at all similar to Albanian ones.

\subsection{Similarity with L1}

Some of the expressions in English have the Albanian equivalents, which means they are very similar in structure and meaning. They were included in the questionnaire in order to see how the native language helps in understanding the meaning of idiomatic expressions in a foreign language. In the list of the English expressions, in brackets, we have given the Albanian equivalent expressions (see Appendix I). We can state that these expressions were much easier to be understood by the students. They can also make correct use of them in sentences of their own. Here are some examples: I have the name of the book on the tip of my tongue. She can twist him round her little finger, he's very dependent on her. When she found out what he had done, she lost her temper. Let's forget about the past, it's time to turn over a new leaf. 
He's got lung cancer, I'm sorry he's at death's door. Lucky her! She can lead her husband by the nose. When I went to Tirana, I felt like a fish out of water. Don't feel sorry for him, they're just crocodile tears.

On the other hand, there is the expression to put a spoke in someone's wheel, which has its equivalent in Albanian (t'i vësh shkopinjtë në rrotë dikujt), but which most of the students do not understand, even when its definition is given. It is obvious that the other expressions, which are different, are much more difficult to be detected and used in the right way by the students.

\subsection{Making sentences}

After taking into consideration the definitions of the expressions and the contexts in which they were used, the students were also requested to make simple sentences of their own to use the expressions in both languages. Understanding fixed idiomatic expressions and interpreting them is as important as using them in the proper way and context. After all, the main purpose of why people learn them is to be able to use them (see 3.1).

\section{Concluding remarks}

The results from the questionnaire indicated that fixed expressions are hard to be understood and learned in L1 and L2. After having carefully considered the students' answers, we can draw these conclusions: First, the students know most of the expressions in Albanian simply because they have heard them more often. They do not find it very difficult to use them correctly and sometimes even by paraphrasing them with other similar expressions although "There are semantic as well as pragmatic constrains on idioms' use that go beyond the scope of a simple paraphrase" (Cacciari 1993, p. 27). Secondly, it is much more difficult for them to detect the meaning of the unknown English expressions even when they are used in context or their definition is given. We can say that the English expressions, which have equivalent counterparts in Albanian, are understood and used in the proper way, although not always. Thirdly, we also noticed that the students find it easier to detect the meaning of the unknown expression in both L1 and L2 when they are given the definition than when they are used in context. Lastly, we would conclude that comprehension and interpretation of the unknown idiomatic expressions is difficult because of their special features. Out of context, their meanings are difficult to be detected in the native and foreign language as well. But acquiring and using them in the proper context or situation is harder. These tendencies hold true for learners of English or any other language in the world.

\section{References}

Alexander, R. J. (1987). Fixed expressions in English: a linguistic, psychological, sociolinguistic and didactic study. (part I). Anglistik und Englischunterricht.

Barkema, H. (1993). Idiomacity and Terminology. ms., University of Nijmegen, Netherlands.

Cacciari, C. (1993). The Place of Idioms in a Literal and Metaphorical World, in Cacciari, C., Tabossi, P. eds. Idioms; Processing, Structure and Interpretation. Lawrence Erlbaum Associates, Hillsdale, New Jersey.

Carter, R. (1987). Vocabulary. London: Allen and Unwin.

Curry, N. (1994). Illustrated American Idioms. The Materials Branch English language programs Division US Information Agency, Washington, DC 20547

Çeliku, M. (1962). Togfjalësha të Qëndrueshëm Foljorë në Shqipen e Sotme. Buletin i Universitetit Shtetëror të Tiranës, Seria Shkencat Shoqërore.

Everaert, M. et al. eds. (1995). Idioms; Structural and Psychological Perspectives. Lawrence Erlbaum Associates, Hillsdale, New Jersey. Liu, D. (2008). Idioms; Description, Comprehension, Acquisition, and Pedagogy. ESL \& Applied Linguistics Professional Series.

Moon, R. (1998). Fixed expressions and Idioms in English. Oxford: Clarendon Press.

Mustafa, N. (1984). Shprehje Popullore nga Rrethi i Korçës. SF. Nr. 1.

Samara, M. (1981). Antonimia e Togfjalëshave të Qëndrueshëm në Gjuhën e Sotme Shqipe. SF, Nr. 4.

Seidl, J./McMordie. (1978). English Idioms and how to use them. Oxford University Press.

Appendix I: The list of English and Albanian fixed expressions included in the questionnaire:

\begin{tabular}{|l|l|}
\hline English fixed expressions & \multicolumn{2}{|l|}{ Albanian fixed expressions } \\
\hline 1. By word of mouth: & 1. Bën allatkë me dikë: \\
2. Come out of one's shell: & 2. Nga avllia duket shtëpia: \\
3. Get it in the neck: & 3. Mos na bëj baltë: \\
4. Get the message: (marr mesazhin) & 4. S'të jep as barin e zgjebes dikush: \\
\hline
\end{tabular}


5. Give (lend) an ear to: (I vë veshin diçkaje ose dikujt)

6. Hard act to follow:

7. Head over hills:

8. Keep one's fingers crossed: (të kryqëzosh gishtat)

9. Lose one's temper: (të humbësh toruan)

10. Out of circulation:

11. Pop the question:

12. Save for a rainy day:

13. Skate on thin ice:

14. Snake in the grass:

15. Straight from the horse's mouth

16. Take it easy:

17. Crocodile tears: (lotë krokodili)

18. A blind date:

19. A wet blanket:

20. A fish out of water: (si peshku pa ujë)

21. The salt of the world:

22. A skeleton in the cupboard:

23. To put a spoke in someone's wheel: (t'i vësh shkopinjtë në rrotë dikujt)

24. A storm in a tea-cup:

25. To call someone names:

26. To drop a line to someone: (t'i shkruah dikujt një rresht)

27. To raise one's glass to someone: (të ngresh dolli për shëndetin e dikujt)

28. To lead someone by the nose: (ta tërheqësh dikë prej hunde)

29. By and large:

30. To be born under a lucky star:

31. To be at death's door: (të jesh në prag të vdekjes)

32. To get the sack:

33. To give someone the cold shoulder:

34. To pull someone's leg:

35. To turn over a new leaf: (të kthesh një faqe të re)

36. To spill the beans:

37. To kick the bucket:

38. To catch someone red-handed;

39. To twist someone round one's (little) finger: (ta vërtitësh dike me gishtin e vogël)

40. To have something on the tip of one's tongue: (ta kesh diçka në majë të gjuhës)
5. Të kam parë edhe në behar:

6. Mos dil si bishti i plumbit:

7. E zbraz koburen që në brez dikush:

8. Nuk do të vësh brirët:

9. I mbështolli (mblodhi) buzët dikush:

10. Të pëlcet buzën dikush:

11. Godet me një çekan dikush:

12. S'bëhet dasma me një këngë;

13. Në mes të daulles një zurna:

14. Është dielli me dhëmbë;

15. M'u bë si dimër i dytë dikush:

16. Të bien dorës:

17. S'vë dorën në thikë:

18. I ka drutë e thata dikush:

19. Sikur e ka ngrënë më dhëmbë:

20. I ngriftë dhjamët e syrit:

21. Kërkon erën nëpër fushë dikush:

22. Fshij e pa fshirë:

23. Ia nxori fundin çikrikut:

24. Var këmborën sa ke qafën:

25. Më lëshon koka miza:

26. I vaiti koka në tavan dikujt:

27. Sa ke kopsën, hap vrimën:

28. Ia theu kryqet dikujt:

29. I ngeli këmba në gurë:

30. Mos hidh kripë në poçe të tjetrit:

31. Sikur e kanë hequr për leshi dikë:

32. S'varet mali në peronë:

33. S'tundet mali nga dëbora:

34. Iu ngjallën pleshtat dikujt:

35. Na hëngri pragun e shtëpisë:

36. I rëndon qimja në trup dikujt:

37. I ka vënë synë diellit:

38. I ngeci sharra në gdhë:

39. S'ra sheqeri në ujë:

40. E ka xhepin kukurec dikush: 